\title{
PdPb-Catalyzed Decarboxylation of Proline to Pyrrolidine: Highly Selective Formation of a Biobased Amine in Water
}

\author{
Jasper Verduyckt, ${ }^{\dagger}$ Maarten Van Hoof, ${ }^{\dagger}$ Free De Schouwer, $^{\dagger}$ Marike Wolberg, $^{\dagger}$ Mert Kurttepeli, $^{\ddagger}$ \\ Pierre Eloy, ${ }^{\perp}$ Eric M. Gaigneaux, ${ }^{\text {II }}$ Sara Bals, ${ }^{\ddagger}$ Christine E. A. Kirschhock, ${ }^{\dagger}$ and Dirk E. De Vos ${ }^{*}{ }^{\dagger}$ \\ ${ }^{\dagger}$ Centre for Surface Chemistry and Catalysis, Department of Microbial and Molecular Systems, KU Leuven-University of Leuven, \\ Leuven Chem\&Tech, Celestijnenlaan 200F, Post Box 2461, 3001 Heverlee, Belgium \\ ${ }^{\ddagger}$ Electron Microscopy for Materials Science, UA-University of Antwerp, Groenenborgerlaan 171, 2020 Antwerp, Belgium \\ ${ }^{\S}$ Institute of Condensed Matter and Nanosciences, ${ }^{\perp}$ SUrface CHaracterization platform (SUCH), and ${ }^{\mathrm{I}}$ MOlecules Solids \& \\ reactiviTy (MOST), UCL-Université Catholique de Louvain, Place L. Pasteur 1, Post Box L4.01.09, 1348 Louvain-la-Neuve, \\ Belgium
}

\section{Supporting Information}

\begin{abstract}
Amino acids have huge potential as platform chemicals in the biobased industry. Pd-catalyzed decarboxylation is a very promising route for the valorization of these natural compounds derived from protein waste or fermentation. We report that the highly abundant and nonessential amino acid L-proline is very reactive in the Pd-catalyzed decarboxylation. Full conversions are obtained with $\mathrm{Pd} / \mathrm{C}$ and different $\mathrm{Pd} / \mathrm{MeO}_{x}$ catalysts; this allowed the identification of the different side reactions and the mapping of the reaction network. Due to the high reactivity of pyrrolidine, the selectivity for pyrrolidine was initially low. By carefully modifying $\mathrm{Pd} / \mathrm{ZrO} 2$ with $\mathrm{Pb}$ in a controlled manner-via two incipient wetness impregnation steps-the selectivity increased remarkably. Finally, a thorough investigation of the reaction parameters resulted in an increased activity of this modified catalyst and an even further enhanced selectivity under a low $\mathrm{H}_{2}$ pressure of 4 bar at $235{ }^{\circ} \mathrm{C}$ in water. This results in a very selective and sustainable production route for the highly interesting pyrrolidine.
\end{abstract}

KEYWORDS: $P d P b$, decarboxylation, L-proline, pyrrolidine, biobased amine, water

\section{INTRODUCTION}

Amines are versatile building blocks for the synthesis of organic compounds, such as dyes, agrochemicals, and pharmaceuticals. ${ }^{1}$ For example, pyrrolidine is used in the synthesis of nicotine and rifamycin antibiotics. ${ }^{2,3}$ Currently, this secondary amine is produced via the high-temperature dehydration of 1,4butanediol in the presence of ammonia using, for example, a $\mathrm{ThO}_{2}-\mathrm{Al}_{2} \mathrm{O}_{3}$ catalyst at $300{ }^{\circ} \mathrm{C} .{ }^{1}$ The diol on its turn is synthesized via oxidation of the fossil-based butane to maleic anhydride, which is subsequently hydrogenated to 1,4butanediol in the DAVY process. ${ }^{4}$ The different redox transformations render this route to pyrrolidine very inefficient. In this work, we propose an alternative sustainable pathway for the synthesis of this important amine, starting from the amino acid $\mathrm{L}$-proline as a renewable resource.

Amino acids can be produced in a green way via fermentation. ${ }^{5,6}$ More importantly, however, they will become increasingly available from protein-rich waste streams. ${ }^{7}$ Common agricultural waste fractions such as poultry feathers, dried distillers grains with solubles and press cakes from rapeseed, soybeans, algae, among others, contain up to $90 \%$ of proteins. ${ }^{8}$ Sanders et al. predict that in this way more than 100 million tons of protein will be available if $10 \%$ of the fossil transportation fuel is replaced by biomass-derived fuels. ${ }^{9}$ Workup of these proteins includes extraction, hydrolysis, and subsequent separation of the amino acids. This final step still remains a big challenge, though new technologies based on electrodialysis and adsorption are emerging. ${ }^{10-14}$

Amino acids have huge potential as platform chemicals in the biobased industry. ${ }^{7}$ They can be catalytically converted to valuable nitriles via oxidative decarboxylation ${ }^{15-18}$ and to amino alcohols via hydrogenation. ${ }^{19,20}$ Another very interesting class of valorization reactions is the direct decarboxylation to form amines. This reaction is catalyzed by enzymes or by $\alpha, \beta$ unsaturated ketones that mimic the pyridoxal 5'-phosphate cofactor. $^{10,11,21}$ The use of enzymes suffers however from the need for an expensive cofactor in combination with a strict $\mathrm{pH}$ control and from a low volumetric productivity. ${ }^{10,11,22}$ The use of homogeneous organocatalysts, on the other hand, suffers from the mandatory use of an organic solvent in combination with high catalyst loading and difficult catalyst recycling. ${ }^{21} \mathrm{~A}$ viable alternative is the direct Pd-catalyzed decarboxylation, which was first applied to the decarboxylation of fatty acids for

Received: September 7, 2016

Published: September 16, 2016 
Table 1. Pd Catalyst Screening for the Decarboxylation of L-Proline to Pyrrolidine

\begin{tabular}{|c|c|c|c|c|c|c|c|}
\hline & \multirow[b]{2}{*}{ catalyst } & \multirow[b]{2}{*}{ conversion $[\%]$} & \multicolumn{5}{|c|}{ selectivity [\%] } \\
\hline & & & pyrrolidine & $\mathrm{DKP}^{b}$ & pathway $\mathrm{A}^{c}$ & pathway $\mathrm{B}^{d}$ & pathway $\mathrm{C}^{e}$ \\
\hline 1 & $\mathrm{Pd} / \mathrm{C}$ & $>99$ & 2 & $<1$ & 7 & 14 & 77 \\
\hline 2 & $\mathrm{Pd} / \mathrm{Al}_{2} \mathrm{O}_{3}$ & 98 & 16 & $<1$ & 25 & 16 & 43 \\
\hline 3 & $\mathrm{Pd} / \mathrm{BaSO}_{4}$ & 64 & 33 & 19 & 11 & 3 & 34 \\
\hline 4 & $\mathrm{Pd} / \mathrm{CaCO}_{3}$ & $>99$ & 5 & 9 & 12 & 1 & 73 \\
\hline 5 & $\mathrm{Pd} / \mathrm{MgAl}_{2} \mathrm{O}_{4}$ & $>99$ & 6 & $<1$ & 5 & 35 & 54 \\
\hline 6 & $\mathrm{Pd} / \mathrm{ZrO}_{2}$ & $>99$ & 10 & $<1$ & 27 & 17 & 46 \\
\hline 7 & $\mathrm{PdPb} / \mathrm{CaCO}_{3}$ & 64 & 41 & 23 & 2 & 5 & 29 \\
\hline 8 & $\mathrm{PdPb} / \mathrm{MgAl}_{2} \mathrm{O}_{4}$ & 72 & 40 & 14 & 3 & 6 & 37 \\
\hline 9 & $\mathrm{PdPb} / \mathrm{ZrO}_{2}(\mathrm{~A})$ & 44 & 50 & 21 & 9 & 9 & 11 \\
\hline 10 & $\mathrm{Pd} / \mathrm{Al}_{2} \mathrm{O}_{3}^{f}$ & 56 & 25 & $<1$ & 29 & 5 & 41 \\
\hline 11 & $\mathrm{Pd} / \mathrm{ZrO}_{2}^{f}$ & 40 & 25 & $<1$ & 32 & 10 & 33 \\
\hline 12 & $\mathrm{PdPb} / \mathrm{ZrO}_{2}(\mathrm{~B})$ & 45 & 67 & 11 & 2 & 20 & $<1$ \\
\hline 13 & - & 16 & 37 & 63 & $<1$ & $<1$ & $<1$ \\
\hline
\end{tabular}

${ }^{a}$ Reaction conditions: L-proline $(0.2 \mathrm{mmol}), 4 \mathrm{~mol} \% \mathrm{Pd}$, water $(2 \mathrm{~mL}), 225{ }^{\circ} \mathrm{C}, 6$ bar $\mathrm{N}_{2}, 6 \mathrm{~h} .{ }^{b}$ Cyclodi-L-prolyl, a diketopiperazine. ${ }^{c}$ Side product from Pathway A is pyrrole. "Pathway B" represents 1-pyrroline, 2-pyrrolidone, propionic acid, butyric acid, $\gamma$-hydroxybutyric acid, and $\gamma$ butyrolactone. "Pathway C" represents $n$-butylamine and mass loss from solution, resulting in the formation of propane and other volatiles. $f_{215}{ }^{\circ} \mathrm{C}$.

Scheme 1. Reaction Network for the Decarboxylation of L-Proline

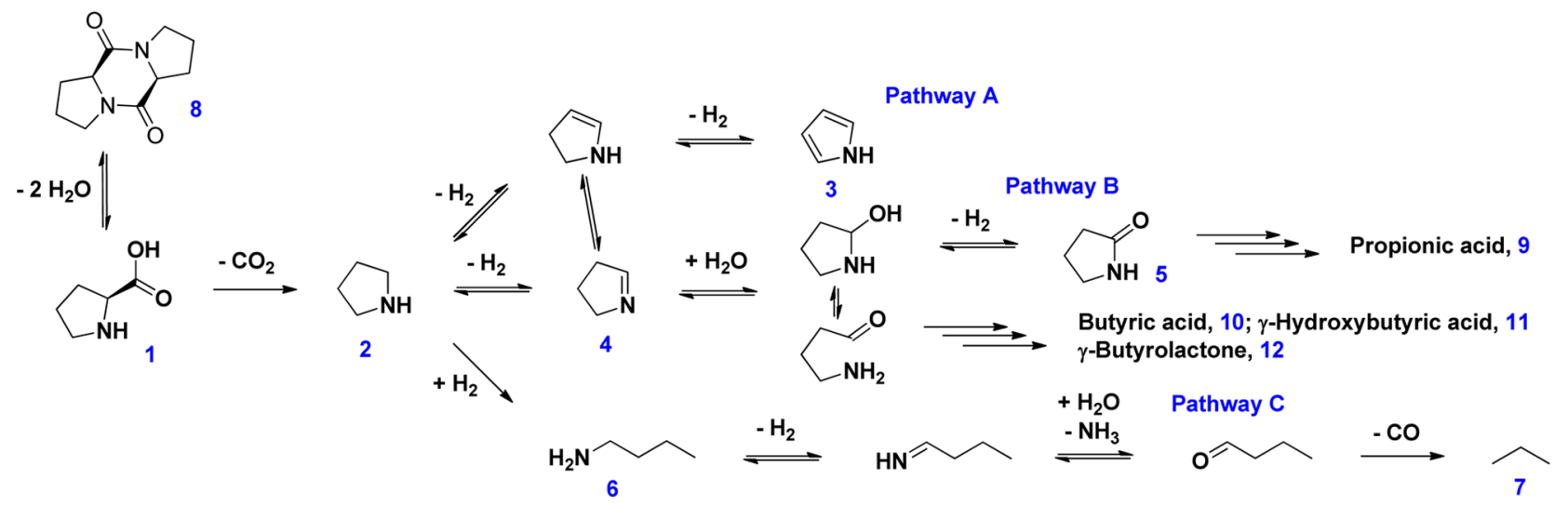

${ }^{a}$ The detailed identification of the observed (numbered) compounds is given in the Supporting Information.

the production of diesel-like compounds at $300{ }^{\circ} \mathrm{C} .{ }^{23,24}$ Typically, the reaction is conducted with zerovalent $\mathrm{Pd}$ nanoparticles on a support. Recently, this technology was successfully adapted for the decarboxylation of itaconic acid to methacrylic acid and of (pyro)glutamic acid to 2-pyrrolidone in water at $250{ }^{\circ} \mathrm{C} .{ }^{25,26}$ The extension of this technology to the production of amines from other amino acids has so far not been reported, obviously due to the instability of amines under these reaction conditions.

In this work, the Pd-catalyzed decarboxylation is successfully extended to the first highly selective formation of a biobased amine in water, using L-proline as the substrate. An essential step to obtain high selectivities was the careful modification of the $\mathrm{Pd}$ catalyst with $\mathrm{Pb}$ via a new, controlled two-step incipient wetness approach.

\section{RESULTS AND DISCUSSION}

Pd Catalyst Screening and Unraveling the Complex Reaction Network. In an initial screening, different Pd catalysts were tested for the decarboxylation of L-proline (1) to pyrrolidine (2) with water as the solvent, using $4 \mathrm{~mol} \% \mathrm{Pd}$ at 6 bar $\mathrm{N}_{2}$ and $225{ }^{\circ} \mathrm{C}$ for $6 \mathrm{~h}$ (Table 1 , entries 1-6). These reaction conditions were inspired by those recently reported by our group for the decarboxylation of pyroglutamic acid. ${ }^{26}$ In general, L-proline ( $\mathbf{1})$ is very reactive for the decarboxylation because almost all catalysts attain full conversion already at 225 ${ }^{\circ} \mathrm{C}$. The high conversions obtained with different catalysts allowed to identify the side products and hence to map the reaction network (Scheme 1). Due to its high reactivity, the selectivity to pyrrolidine (2) was initially low (2-33\%). The first side route is the dehydrogenation of pyrrolidine (2) to form pyrrole (3, pathway A), which was observed especially for $\mathrm{Pd} / \mathrm{Al}_{2} \mathrm{O}_{3}$ and $\mathrm{Pd} / \mathrm{ZrO}_{2}$. This reaction is known to be Pdcatalyzed; group-IV metal oxide supports, like $\mathrm{ZrO}_{2}$ and $\mathrm{TiO}_{2}$, are known to favor the pyrrolidine dehydrogenation. ${ }^{27}$ Pathway B leads to a plethora of side products, starting with a single dehydrogenation to form 1-pyrroline (4), which was identified using ${ }^{1} \mathrm{H}$ NMR and GC-MS. This cyclic imine is hydrated to pyrrolidin-2-ol and its linear counterpart $\gamma$-aminobutyraldehyde. The cyclic amino alcohol is then again dehydrogenated to form 2-pyrrolidone (5). The latter is rather stable, but can be hydrolyzed to a minor extent, which consecutively opens the route to propionic acid (9). ${ }^{26}$ The linear amino aldehyde is less stable and is most probably the origin of more side products, such as butyric acid (10), $\gamma$-hydroxybutyric acid (11), and $\gamma$ butyrolactone (12). The most important pathway $\mathrm{C}$ is initiated by the ring opening hydrogenolysis of pyrrolidine (2). ${ }^{28} \mathrm{H}_{2}$ can be generated in situ in the water-gas shift reaction of $\mathrm{CO}$ 
formed in decarbonylation reactions (cf. below). ${ }^{26}$ In this way $n$-butylamine (6) is formed, which is subsequently fully defunctionalized to propane (7) and other volatile compounds. The presence of propane (7) was proven by performing gas phase Fourier transform infrared spectroscopy (FTIR) on the headspace of the reaction in entry 1 (Table 1 ). $n$-Butylamine (6) was merely observed in trace amounts because it is highly reactive and readily defunctionalized to propane (7) and other volatiles. This was demonstrated with a reaction under the same conditions, starting from the linear amine: $n$-butylamine (6) was converted for $92 \%$, and only traces of products could be found in solution, while $\mathrm{CO}, \mathrm{CO}_{2}, \mathrm{NH}_{3}$, and propane (7) were detected in the gas phase. The equilibrium between $\mathrm{CO}$ and $\mathrm{CO}_{2}$ was clearly in favor of $\mathrm{CO}_{2}\left(\mathrm{CO} / \mathrm{CO}_{2}=0.04\right)$; this confirms the occurrence of the water-gas shift reaction under these conditions. Finally, if L-proline (1) is not converted quickly enough, it gets the opportunity to react through a double intermolecular condensation; this gives rise to the diketopiperazine cyclodi-L-prolyl (8). This reaction represents most of the conversion in the blank reaction (Table 1 , entry 13). The detailed identification of the observed compounds is given in the Supporting Information.

Modification with $\mathrm{Pb}$. In search for a more selective catalyst to transform L-proline (1) into pyrrolidine (2), the modification of $\mathrm{Pd}$ with $\mathrm{Pb}$ was explored (Table 1, entries 79). Besides the commercially available $\mathrm{PdPb} / \mathrm{CaCO}_{3}$, also $\mathrm{PdPb}$ supported on a more acidic $\left(\mathrm{ZrO}_{2}\right)$ and a more basic $\left(\mathrm{MgAl}_{2} \mathrm{O}_{4}\right)$ support were synthesized. The catalysts were prepared via a one-step impregnation with $\left(\mathrm{NH}_{3}\right)_{4} \mathrm{PdCl}_{2}$ together with $\mathrm{Pb}\left(\mathrm{NO}_{3}\right)_{2}$ according to Furukawa et al., ${ }^{29}$ followed by calcination and reduction. This clearly has a beneficial effect; the selectivity toward pyrrolidine (2) typically increases with more than $30 \%$, irrespective of the support. $\mathrm{PdPb} / \mathrm{ZrO}_{2}$ (A), the most selective catalyst so far, already displays a pyrrolidine selectivity of $50 \%$ at $44 \%$ conversion. One might think that this increase is just due to a decrease in conversion. However, when samples were analyzed at lower conversions using the conventional Pd catalysts, the selectivity never exceeded $25 \%$ (Table 1 , entries 10-11). The selectivity increase is mainly due to the suppression of pathway $C$; ring opening hydrogenolysis of pyrrolidine (2), which opens the route toward propane (7), seems to be inhibited by the addition of $\mathrm{Pb}$ to $\mathrm{Pd}$. Nevertheless, the latter reaction route is not completely blocked yet. This most likely results from the incomplete modification of Pd. Therefore, the most selective catalyst was synthesized in a new, controlled manner to carefully modify all Pd sites. In this new method, first Pd was distributed onto the $\mathrm{ZrO}_{2}$ support by incipient wetness impregnation; subsequently, the material was dried and calcined to remove the ligands. Afterward, $\mathrm{Pb}$ was evenly deposited onto Pd by a second incipient wetness impregnation step. After a final drying, calcination, and reduction step, $\mathrm{PdPb}$ / $\mathrm{ZrO}_{2}$ (B) was obtained. For this newly synthesized catalyst, the selectivity toward pyrrolidine (2) further increased up to $67 \%$ (Table 1, entry 12). Now the ring opening hydrogenolysis of pyrrolidine (2) is completely blocked, owing to the efficient modification of all $\mathrm{Pd}$ sites with $\mathrm{Pb}$. In addition, $\mathrm{Pb}$ also significantly suppresses the dehydrogenation path toward pyrrole (3).

In order to prove that the higher selectivity of $\mathrm{PdPb} / \mathrm{ZrO}_{2}$ (B) compared to $\mathrm{PdPb} / \mathrm{ZrO}_{2}$ (A) is due to the better coverage of $\mathrm{Pd}$ with $\mathrm{Pb}$, both catalysts were extensively characterized by high-angle annular dark field-scanning transmission electron microscopy (HAADF-STEM) in combination with energy dispersive X-ray spectroscopy (EDX), by high-resolution powder X-ray diffractometry (XRD) and by $\mathrm{CO}$ chemisorption. The particle size distribution of both samples was rather narrow with most of the nanoparticles situated between 4 and $8 \mathrm{~nm}$ (Figure S1). However, the high-resolution X-ray diffractogram of the $\mathrm{PdPb} / \mathrm{ZrO}_{2}$ (A) sample shows unambiguous signals of a pure Pd phase (Figure 1). This clearly indicates that not all Pd

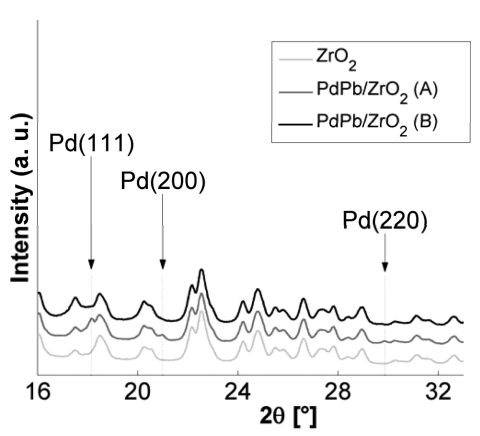

Figure 1. High-resolution diffractograms of $\mathrm{PdPb} / \mathrm{ZrO}_{2}$ catalysts. The full pattern of $\mathrm{Pd}$ can be found in the Supporting Information (Figure S4).

is intimately mixed with $\mathrm{Pb}$. Such signals are totally absent in the diffractogram of $\mathrm{PdPb} / \mathrm{ZrO}_{2}(\mathrm{~B})$. $\mathrm{Pd}$ and $\mathrm{Pb}$ were used in the synthesis in a 3-to- 1 molar ratio to produce the $\mathrm{Pd}_{3} \mathrm{~Pb}$ alloy, which was proposed by Furukawa et al. ${ }^{29}$ No evidence for this alloy was found in the XRD data, although this might be due to the much smaller nanoparticles formed in our synthesis, viz., 4-8 $\mathrm{nm}$ versus $14-20 \mathrm{~nm}$. HAADF-STEM imaging accompanied by EDX analysis was performed in order to determine the nature of the elements at the catalyst surface. Figure 2 presents HAADF-STEM images (Figure 2a,g) and EDX elemental maps (Figure $2 \mathrm{~b}-\mathrm{e}, \mathrm{h}-\mathrm{k}$ ) of both the $\mathrm{PdPb} / \mathrm{ZrO}_{2}$ (A) and $\mathrm{PdPb} / \mathrm{ZrO}_{2}$ (B) sample. The observed signals from $\mathrm{Pd}$ and $\mathrm{Pb}$ are visualized in red and green, respectively. By overlaying the EDX elemental maps of the $\mathrm{Pd}$ and $\mathrm{Pb}$, it is clear that for $\mathrm{PdPb} / \mathrm{ZrO}_{2}(\mathrm{~A})$, the presence of $\mathrm{Pd}$ does not always correspond to the presence of $\mathrm{Pb}$ (Figure 2f). However, for $\mathrm{PdPb} / \mathrm{ZrO}_{2}$ (B), the presence of Pd predominantly coincides with the presence of $\mathrm{Pb}$ (Figure 21). These measurements therefore confirm the hypothesis that $\mathrm{Pd}$ is much better covered by $\mathrm{Pb}$ in $\mathrm{PdPb} / \mathrm{ZrO}_{2}$ (B) than in $\mathrm{PdPb} / \mathrm{ZrO}_{2}$ (A). In addition, $\mathrm{CO}$ chemisorption experiments showed a lower apparent $\mathrm{Pd}$ dispersion for $\mathrm{PdPb} / \mathrm{ZrO}_{2}$ (B) compared to $\mathrm{PdPb}$ / $\mathrm{ZrO}_{2}$ (A): $2.9 \%$ vs $4.7 \%$ (Table 2). Since HAADF-STEM revealed very similar Pd particle size distributions for both catalysts, this difference is attributed to the better coverage of $\mathrm{Pd}$ by $\mathrm{Pb}$ in $\mathrm{PdPb} / \mathrm{ZrO}_{2}(\mathrm{~B})$ : when $\mathrm{Pb}$ is better covering the $\mathrm{Pd}$ surface, less $\mathrm{CO}$ is able to adsorb onto that surface. The same effect was observed in literature for $\mathrm{CO}$ chemisorption on $\mathrm{Pd}$ nanoparticles decorated or alloyed with $\mathrm{Ga}_{2} \mathrm{O}_{3}, \mathrm{Sn}, \mathrm{K}, \mathrm{Mn}$, and $\mathrm{Cu}^{30-32}$ Finally, X-ray photoelectron spectroscopy was performed to determine the electronic state of $\mathrm{Pd}$ and $\mathrm{Pb}$ in $\mathrm{Pd} / \mathrm{ZrO}_{2}$ and $\mathrm{PdPb} / \mathrm{ZrO}_{2}$ catalysts (Table S1, Figure S2,S3). $\mathrm{Pd}$ was always in the metallic state, characterized by $3 \mathrm{~d}_{5 / 2}$ emission peaks at $335.5 \mathrm{eV}$. This value corresponds very well with the $335.4 \mathrm{eV}$ that was previously reported for $\mathrm{Pd}^{0} / \mathrm{ZrO}_{2}{ }^{33}$ $\mathrm{Pb}$ was in all catalysts present in both metallic and cationic states, as determined from $4 f_{7 / 2}$ emission peaks at 136.6 and $138.8 \mathrm{eV}$, respectively. These values are in accordance with 

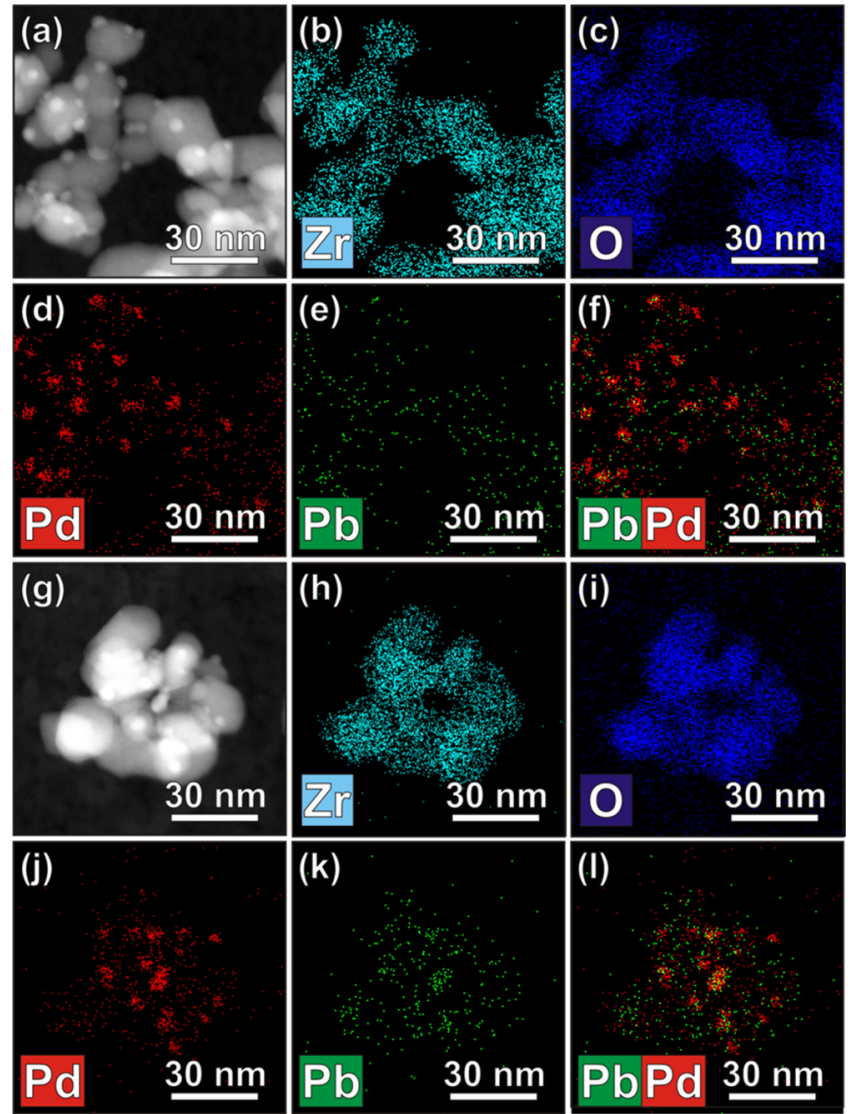

Figure 2. (a),(g) HAADF-STEM images and (b-e) and (h-k) EDX elemental maps of $\mathrm{PdPb} / \mathrm{ZrO}_{2}$ (A) (top two rows) and $\mathrm{PdPb} / \mathrm{ZrO}_{2}$ (B) (bottom two rows). The overlap of the $\mathrm{Pd}$ and $\mathrm{Pb}$ signals can be studied from the mixed EDX elemental maps presented in (f) and (l).

Table 2. Pd Dispersion of $\mathrm{Pd} / \mathrm{ZrO}_{2}$ and $\mathrm{PdPb} / \mathrm{ZrO}_{2}$ Catalysts Determined via CO Chemisorption

\begin{tabular}{cccc} 
& $\mathrm{Pd} / \mathrm{ZrO}_{2}$ & $\mathrm{PdPb} / \mathrm{ZrO}_{2}(\mathrm{~A})$ & $\mathrm{PdPb} / \mathrm{ZrO}_{2}(\mathrm{~B})$ \\
\hline
\end{tabular}

those reported for $\mathrm{Pb}^{0}(137.1 \mathrm{eV})$ and $\mathrm{PbO}_{2}(139.1 \mathrm{eV}) .^{34}$ The presence of cationic $\mathrm{Pb}$ species might originate from exposure of the catalysts to air prior to the analysis; or it could mean that $\mathrm{Pb}$ was not fully reduced during the catalyst synthesis. XPS did not give evidence for an influence of $\mathrm{Pb}$ on the electronic structure of $\mathrm{Pd}$.

Fine-Tuning the Reaction Conditions. The modified $\mathrm{PdPb} / \mathrm{ZrO}_{2}$ (B) material is so far the best catalyst: it produces pyrrolidine (2) starting from L-proline (1) with a $67 \%$ selectivity, albeit at a rather low conversion of $45 \%$. Nonetheless, side products from pathway $B$, as well as the diketopiperazine (8) are still formed. Further efforts are therefore devoted to increasing the rate of the catalytic reaction and to blocking the dehydrogenation that initiates pathway $\mathrm{B}$.

Therefore, first a temperature increase was investigated (Table 3). An increasing temperature leads to an increased conversion; at the optimum of $235{ }^{\circ} \mathrm{C}$, the selectivity was not affected. However, at a temperature of $245{ }^{\circ} \mathrm{C}$, ring opening hydrogenolysis of pyrrolidine (2) became prominent again, with a reappearance of pathway $\mathrm{C}$ side products.

Next, the addition of $\mathrm{H}_{2}$ to the reaction atmosphere was explored (Table 4). A low $\mathrm{H}_{2}$ pressure of 4 bar has a remarkably favorable influence on the activity of the $\mathrm{PdPb}$ / $\mathrm{ZrO}_{2}$ (B) catalyst: a conversion of $88 \%$ is now reached within 6 $\mathrm{h}$, with the decarboxylation as the dominant initial reaction (entries 1-2). In this reducing atmosphere, Pd more readily remains in its active zerovalent state. ${ }^{35,36}$ In addition, the selectivity increases to $76 \%$, largely owing to the inhibition of the secondary dehydrogenation toward pyrrole (3, pathway $\mathbf{A})$. When the $\mathrm{H}_{2}$ pressure was increased to $10 \mathrm{bar}$, again ring opening hydrogenolysis became difficult to impede (entry 3). A further increase to 15 bar $\mathrm{H}_{2}$ is even detrimental to the conversion level, either because $\mathrm{H}_{2}$ occupies the active sites or because sintering of the metallic nanoparticles occurs (entry 4 ). For the reaction at 4 bar $\mathrm{H}_{2}$, the stirring rate was varied (Table S3). This did not result in higher conversions, indicating that there are no significant mass-transfer limitations.

Lastly, Table 5 studies the influence of the $\mathrm{pH}$ on the reaction, and especially its effect on pathway $B$, which is the only significant side route that subsists for the optimized reaction (Table 4, entry 2). The $\mathrm{pH}$ was adjusted using $\mathrm{H}_{3} \mathrm{PO}_{4}$ or $\mathrm{NaOH}$; the natural $\mathrm{pH}$ of the starting solution at room temperature is 7 . Both a more acidic and a more alkaline $\mathrm{pH}$ decrease the conversion. The alkaline environment induces a number of unidentified side reactions, decreasing the selectivity to pyrrolidine (2). On the other hand, the acidic environment results in a very high selectivity of $91 \%$ at $59 \%$ conversion, with a nearly total suppression of route $B$. The latter can be interpreted in two ways: (i) in acidic conditions the dehydrogenation of pyrrolidine (2) to 1-pyrroline (4) occurs to a much lesser extent or (ii) the decrease in conversion lowers the probability of consecutive side reactions. To verify which of those is the actual reason, a few experiments were conducted as a function of time (Table 5, entries 4-5). When the reaction in the acidic environment was run at longer reaction times to increase the conversion, the selectivity drastically decreased again due to the formation of pathway $\mathrm{B}$ side products. Therefore, the first explanation can be excluded; so the decrease in conversion is responsible for the very high selectivity. This was confirmed by decreasing the conversion of the reaction at neutral $\mathrm{pH}$ by decreasing the reaction time to

Table 3. Temperature Optimization for the Most Selective Catalyst

\begin{tabular}{|c|c|c|c|c|c|c|c|}
\hline & \multirow[b]{2}{*}{ temperature $\left[{ }^{\circ} \mathrm{C}\right]$} & \multirow[b]{2}{*}{ conversion $[\%]$} & \multicolumn{5}{|c|}{ selectivity [\%] } \\
\hline & & & pyrrolidine & $\mathrm{DKP}^{b}$ & pathway $\mathrm{A}^{c}$ & pathway $\mathrm{B}^{d}$ & pathway $\mathrm{C}^{e}$ \\
\hline 1 & 225 & 45 & 67 & 11 & 2 & 20 & $<1$ \\
\hline 2 & 235 & 52 & 69 & 6 & 4 & 21 & $<1$ \\
\hline 3 & 245 & 63 & 56 & 6 & 3 & 21 & 14 \\
\hline
\end{tabular}

${ }^{a}$ Reaction conditions: L-proline $(0.2 \mathrm{mmol}), 4 \mathrm{~mol} \% \mathrm{PdPb} / \mathrm{ZrO}_{2}$ (B), water $(2 \mathrm{~mL}), 6$ bar $\mathrm{N}_{2}, 6 \mathrm{~h} .{ }^{b}$ Cyclodi-L-prolyl, a diketopiperazine. ${ }^{c}$ Side product from Pathway A is pyrrole. "Pathway B" represents 1-pyrroline, 2-pyrrolidone, propionic acid, and butyric acid. "Pathway C" represents mass loss from solution, resulting in the formation of propane and other volatiles. 
Table 4. Effect of Varying Partial Pressures of $\mathrm{H}_{2}$ in the Reaction Atmosphere

\begin{tabular}{|c|c|c|c|c|c|c|c|}
\hline & \multirow[b]{2}{*}{$P_{\mathrm{H}_{2}}[\mathrm{bar}]$} & \multirow[b]{2}{*}{ conversion [\%] } & \multicolumn{5}{|c|}{ selectivity [\%] } \\
\hline & & & pyrrolidine & $\mathrm{DKP}^{b}$ & pathway $A^{c}$ & pathway $\mathrm{B}^{d}$ & pathway $\mathrm{C}^{c}$ \\
\hline 1 & $0^{f}$ & 52 & 69 & 6 & 4 & 21 & $<1$ \\
\hline 2 & 4 & 88 & 76 & 4 & 1 & 19 & $<1$ \\
\hline 3 & 10 & 88 & 64 & 2 & 1 & 9 & 24 \\
\hline 4 & 15 & 27 & 41 & 44 & $<1$ & 15 & $<1$ \\
\hline
\end{tabular}

${ }^{a}$ Reaction conditions: L-proline $(0.2 \mathrm{mmol}), 4 \mathrm{~mol} \% \mathrm{PdPb} / \mathrm{ZrO}_{2}(\mathrm{~B})$, water $(2 \mathrm{~mL}), 235{ }^{\circ} \mathrm{C}, 2$ bar $\mathrm{N}_{2}, 6$ h. ${ }^{b}$ Cyclodi-L-prolyl, a diketopiperazine. ${ }^{c}$ Side product from Pathway A is pyrrole. "Pathway B" represents 1-pyrroline, 2-pyrrolidone, propionic acid, and butyric acid. "ePathway C" represents mass loss from solution, resulting in the formation of propane and other volatiles. ${ }^{f_{6}}$ bar $\mathrm{N}_{2}$.

Table 5. Effect of $\mathrm{pH}$ and Reaction Time

\begin{tabular}{|c|c|c|c|c|c|c|c|c|}
\hline & \multirow[b]{2}{*}{$\mathrm{pH}$} & \multirow[b]{2}{*}{ reaction time $[\mathrm{h}]$} & \multirow[b]{2}{*}{ conversion $[\%]$} & \multicolumn{5}{|c|}{ selectivity [\%] } \\
\hline & & & & pyrrolidine & $\mathrm{DKP}^{b}$ & pathway $\mathrm{A}^{c}$ & pathway B ${ }^{d}$ & $\overline{\text { pathway } \mathrm{C}^{e}}$ \\
\hline 1 & $2^{f}$ & 6 & 59 & 91 & 5 & 2 & 2 & $<1$ \\
\hline 2 & 7 & 6 & 88 & 76 & 4 & 1 & 19 & $<1$ \\
\hline 3 & $12^{g}$ & 6 & 67 & 34 & $<1$ & 3 & 13 & $h$ \\
\hline 4 & $2^{f}$ & 24 & 97 & 55 & 5 & $<1$ & 40 & $<1$ \\
\hline 5 & 7 & 1 & 58 & 95 & $<1$ & 2 & 3 & $<1$ \\
\hline
\end{tabular}

${ }^{a}$ Reaction conditions: L-proline $(0.2 \mathrm{mmol}), 4 \mathrm{~mol} \% \mathrm{PdPb} / \mathrm{ZrO}_{2}(\mathrm{~B})$, water $(2 \mathrm{~mL}), 235{ }^{\circ} \mathrm{C}, 2$ bar $\mathrm{N}_{2}$ and 4 bar $\mathrm{H}_{2} .{ }^{b} \mathrm{Cyclodi}-\mathrm{L}-\mathrm{prolyl}$, a diketopiperazine. ${ }^{c}$ Side product from Pathway A is pyrrole. ${ }^{d “}$ Pathway B" represents 1-pyrroline, 2-pyrrolidone, propionic acid, butyric acid, $\gamma$ hydroxybutyric acid, and $\gamma$-butyrolactone. "Pathway C" represents mass loss from solution, resulting in the formation of propane and other volatiles. ${ }_{\mathrm{pH}}$ was decreased by adding 0.4 equiv of $\mathrm{H}_{3} \mathrm{PO}_{4} \cdot{ }^{g} \mathrm{pH}$ was increased by adding 1 equiv of $\mathrm{NaOH} .{ }^{h}$ Due to the complex product mixture the mass balance could not be determined accurately.

$1 \mathrm{~h}$ : in this way, a selectivity of $95 \%$ was realized at a conversion of $58 \%$ (Table 5, entry 5).

Mechanistic and Kinetic Insights. The new $\mathrm{PdPb}$ catalytic system for the decarboxylation of L-proline (1) to pyrrolidine (2) can now be run at very high selectivities, giving in only a little on the conversion level. The question remains why this modification with $\mathrm{Pb}$ results in a much higher selectivity than that observed for the conventional Pd catalysts. Somorjai and co-workers investigated the formation of pyrrolidine (2) by the hydrogenation of pyrrole (3) at room temperature on $\mathrm{Pt}^{28}$ In this case, the ring opening hydrogenolysis of pyrrolidine (2) to $n$-butylamine (6) could be avoided by lowering the desorption energy of pyrrolidine (2). This amine was shown to be surface-bound by the nitrogen atom. In addition, Furukawa et al. demonstrated that the modification of $\mathrm{Pd}$ with $\mathrm{Pb}$ renders $\mathrm{Pd}$ more electron rich. ${ }^{29}$ Consequently, for the present reaction, $\mathrm{Pd}$ is expected to interact less strongly with the nitrogen atom of pyrrolidine (2), facilitating the desorption of the secondary amine. In this way consecutive side reactions on the $\mathrm{Pd}$ surface, such as ring opening hydrogenolysis can be avoided. In the same way, pyrroline can desorb more easily from the Pd surface, avoiding the further dehydrogenation to pyrrole (3), but also potentially favoring the hydration to the amino alcohol and the amino aldehyde in pathway B. This switch is possible, because 1pyrroline (4) and 2-pyrroline are in tautomeric equilibrium (Scheme 1).

To substantiate the reaction network that is proposed in Scheme 1, the kinetic profiles of two reactions were recorded for the decarboxylation of L-proline (1) under the optimized reaction conditions. Figure 3 depicts the kinetic profile obtained for the highly selective $\mathrm{PdPb} / \mathrm{ZrO}_{2}$ (B) catalyst. At the start of the reaction, pyrrolidine (2) is produced very selectively. Pyrrole (3) and 1-pyrroline (4) quickly reach and maintain a low equilibrium concentration. After $1 \mathrm{~h}$, pyrrolidine (2) starts to convert into 2-pyrrolidone (5), which is clearly

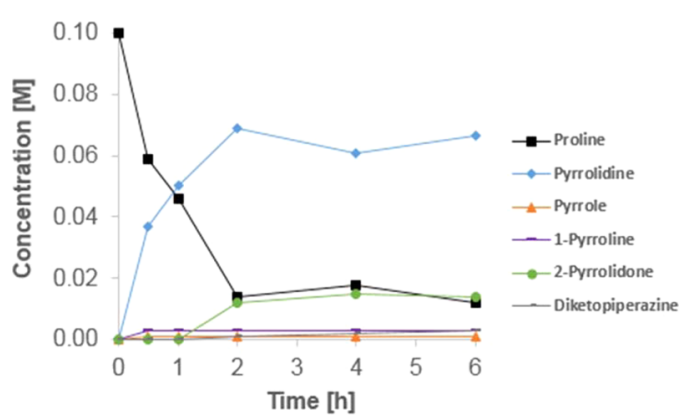

Figure 3. Time course of the decarboxylation of L-proline using $\mathrm{PdPb} /$ $\mathrm{ZrO}_{2}$ (B). Reaction conditions: L-proline $(0.2 \mathrm{mmol}), 4 \mathrm{~mol} \% \mathrm{PdPb} /$ $\mathrm{ZrO}_{2}(\mathrm{~B})$, water $(2 \mathrm{~mL}), 235^{\circ} \mathrm{C}, 2$ bar $\mathrm{N}_{2}$ and 4 bar $\mathrm{H}_{2}$.

formed in a consecutive reaction. This leads to an optimal yield of pyrrolidine (2) of $69 \%$ at $86 \%$ conversion after 2 h. When the catalyst was recycled at this point, the conversion dropped due to an initial deactivation; however, the conversion in the subsequent runs stabilizes at $50-60 \%$ and the selectivity invariably remains very high, that is, more than $90 \%$ (Table S4). Figure 4 presents the kinetic profile of the reaction with $\mathrm{Pd} /$ $\mathrm{ZrO}_{2}$. L-Proline (1) is decarboxylated very fast, and therefore, the first consecutive side reactions are already prominent in the early stages of the reaction. The formation of pyrrole (3) is initially favored by $\mathrm{Pd} / \mathrm{ZrO}_{2}$; this product is however not stable under the applied reaction conditions. Pyrrole (3) is gradually hydrogenated back to pyrrolidine (2), which then reacts via one of the other two prominent pathways. The formation of propane (7, mass loss) therefore steadily increases from the start of the reaction. The concentration of 2-pyrrolidone (5) increases from the beginning as well but reaches a plateau due to the subsequent formation of propionic acid (9). ${ }^{26}$ Unlike propionic acid (9), butyric acid (10) is formed from the start of the reaction and is therefore unlikely to originate from 2pyrrolidone (5). This product is believed to rather stem from $\gamma$ - 


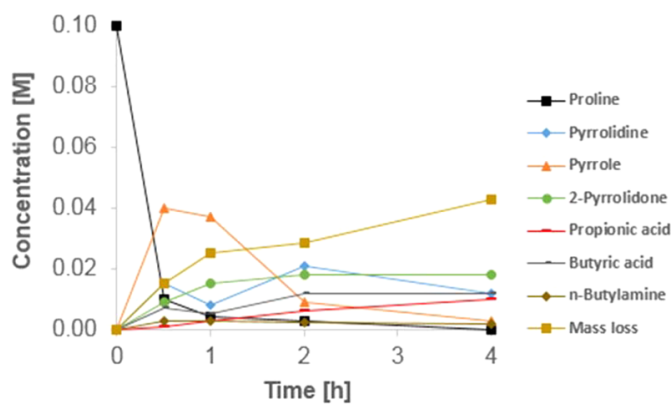

Figure 4. Time course of the decarboxylation of L-proline using $\mathrm{Pd} /$ $\mathrm{ZrO}_{2}$. Reaction conditions: L-proline $(0.2 \mathrm{mmol}), 4 \mathrm{~mol} \% \mathrm{Pd} / \mathrm{ZrO}_{2}$, water $(2 \mathrm{~mL}), 235^{\circ} \mathrm{C}, 2$ bar $\mathrm{N}_{2}$ and 4 bar $\mathrm{H}_{2}$.

aminobutyraldehyde, which is in equilibrium with pyrrolidin-2ol (Scheme 1).

Lastly, in order to confirm some of the hypotheses on consecutive transformation of the pyrrolidine product, pyrrolidine itself was reacted for a short time (Table 6). Ring opening hydrogenolysis, which initiates pathway $\mathbf{C}$, as well as the dehydrogenation to pyrrole (3, pathway A) are clearly impaired by the addition of $\mathrm{Pb}$ (entries $1,3,5$ ). Moreover, the addition of $\mathrm{H}_{2}$ further decreases the formation of pyrrole (3, pathway A) (entries 1, 2, 5, 6).

\section{CONCLUSION}

The Pd-catalyzed decarboxylation has been successfully extended to the highly selective formation of a biobased amine in water. During the initial screening of conventional Pd catalysts for the decarboxylation of the abundant and nonessential L-proline, pyrrolidine turned out to be very labile. The most important side reactions are initiated by either a dehydrogenation, leading to pyrrole, 1-pyrroline, 2-pyrrolidone, and so on, or by the ring opening hydrogenolysis of pyrrolidine to $n$-butylamine, which is further defunctionalized to propane and other volatiles. This led to very poor selectivities as low as $16 \%$ for $\mathrm{Pd} / \mathrm{Al}_{2} \mathrm{O}_{3}$, the best catalyst reported for the decarboxylation of (pyro)glutamic acid to 2-pyrrolidone. Modifying the $\mathrm{Pd}$ catalysts with $\mathrm{Pb}$ was very favorable for the selectivity to pyrrolidine, owing to the blockage of the ring opening hydrogenolysis, as well as the partial inhibition of the dehydrogenation to pyrrole. The one-step impregnation of $\mathrm{Pd}$ together with $\mathrm{Pb}$ however resulted in an incomplete modification of $\mathrm{Pd}$. Therefore, a new, more controlled synthesis procedure based on a two-step incipient wetness approach was introduced. This procedure generated a $\mathrm{PdPb} / \mathrm{ZrO}_{2}$ catalyst in which $\mathrm{Pd}$ is always intimately mixed with $\mathrm{Pb}$, as evidenced by
HAADF-STEM in combination with EDX, by high-resolution $\mathrm{XRD}$ and by $\mathrm{CO}$ chemisorption. Careful exploration of the reaction parameters finally resulted in a very active and selective catalyst under a low $\mathrm{H}_{2}$ pressure at $235^{\circ} \mathrm{C}$ in water. This new sustainable manufacture of pyrrolidine can be run either for $2 \mathrm{~h}$ with a high selectivity $(80 \%)$ at high conversion $(86 \%)$ or for only $1 \mathrm{~h}$ with a very high selectivity $(95 \%)$ at somewhat lower conversion (58\%).

\section{EXPERIMENTAL SECTION}

Materials. All chemicals were used as received: L-proline (Sigma-Aldrich, > 99\%), pyrrolidine (Sigma-Aldrich, 99\%), nbutylamine (Fischer Scientific, laboratory reagent grade), $\mathrm{NaOH}$ (Fischer Scientific, 99.1\%), $\mathrm{H}_{3} \mathrm{PO}_{4}$ (Chem-Lab, 85\% aq solution), $\mathrm{N}_{2}$ (Air Liquide, $\alpha 1$ ), $\mathrm{H}_{2}$ (Air Liquide, $\mathrm{N} 40$ ), $\mathrm{O}_{2}$ (Air Liquide, N25), He (Air Liquide, 99.9997\%), CO (Air Liquide, 99.97\%), Pd/C (5 wt \%, Engelhard), Pd/BaSO 4 (5 wt $\%$, Johnson Matthey), $\mathrm{Pd} / \mathrm{CaCO}_{3}$ (5 wt \%, Johnson Matthey), $\mathrm{PdPb} / \mathrm{CaCO}_{3}$ (5 wt \% Pd, 1 wt \% Pb, Johnson Matthey), $\mathrm{Al}_{2} \mathrm{O}_{3}$ (Condea Chemie, Puralox NGa-150), $\mathrm{MgAl}_{2} \mathrm{O}_{4}$ (SigmaAldrich), $\mathrm{ZrO}_{2}$ (Alfa Aesar), $\left(\mathrm{NH}_{3}\right)_{4} \mathrm{PdCl}_{2} \cdot \mathrm{H}_{2} \mathrm{O}$ (SigmaAldrich, $\geq 99.99 \%), \mathrm{Pb}\left(\mathrm{NO}_{3}\right)_{2}$ (Fluka, > 98\%), benzyl alcohol (Sigma-Aldrich, 99+\%), and $\mathrm{D}_{2} \mathrm{O}$ (Sigma-Aldrich, 99.9\% D).

Catalyst Synthesis. Conventional Pd catalysts (5 wt \%) supported on $\mathrm{Al}_{2} \mathrm{O}_{3}, \mathrm{MgAl}_{2} \mathrm{O}_{4}$ and $\mathrm{ZrO}_{2}$ were synthesized by incipient wetness impregnation according to De Schouwer et $\mathrm{al}^{26}$ In a typical procedure, $1 \mathrm{~g}$ of support was impregnated with a solution of $\left(\mathrm{NH}_{3}\right)_{4} \mathrm{PdCl}_{2}$ in deionized water. Impregnated supports were then dried overnight at $60{ }^{\circ} \mathrm{C}$, granulated to $250-500 \mu \mathrm{m}$ particles, followed by calcination (35 min, $400{ }^{\circ} \mathrm{C}, 2{ }^{\circ} \mathrm{C} / \mathrm{min}, 50 \mathrm{~mL} / \mathrm{min} \mathrm{O}_{2}$ ) and reduction $(1$ h, $400{ }^{\circ} \mathrm{C}, 2{ }^{\circ} \mathrm{C} / \mathrm{min}, 150 \mathrm{~mL} / \mathrm{min} \mathrm{H}_{2}$ ). The synthesized catalysts were stored under $\mathrm{N}_{2}$ until use.

$\mathrm{PdPb} / \mathrm{ZrO}_{2}$ (A) and $\mathrm{PdPb} / \mathrm{MgAl}_{2} \mathrm{O}_{4}$ (5 wt \% Pd, 3.27 wt \% $\mathrm{Pb}$ ) were synthesized by impregnation according to Furukawa et al. ${ }^{29}$ First $\left(\mathrm{NH}_{3}\right)_{4} \mathrm{PdCl}_{2}$ and $\mathrm{Pb}\left(\mathrm{NO}_{3}\right)_{2}(\mathrm{Pd}: \mathrm{Pb}=3: 1$ molar ratio) were dissolved in an aqueous solution $(20 \mathrm{~mL})$ by stirring the solution for $2 \mathrm{~h}$ at $75{ }^{\circ} \mathrm{C}$. One gram of support material was then added; afterward, the stirred slurry was completely dried on the stirring plate at $75{ }^{\circ} \mathrm{C}$. Next, the dried material was granulated to $250-500 \mu \mathrm{m}$ particles, calcined ( 35 min, $400{ }^{\circ} \mathrm{C}, 2{ }^{\circ} \mathrm{C} / \mathrm{min}, 50 \mathrm{~mL} / \mathrm{min} \mathrm{O}_{2}$ ), and subsequently reduced $\left(1 \mathrm{~h}, 600{ }^{\circ} \mathrm{C}, 2{ }^{\circ} \mathrm{C} / \mathrm{min}, 150 \mathrm{~mL} / \mathrm{min}_{2}\right)$. Lastly, the catalysts were stored under $\mathrm{N}_{2}$ until use.

$\mathrm{PdPb} / \mathrm{ZrO}_{2}$ (B) (5 wt \% Pd, 3.27 wt \% $\mathrm{Pb}$ ) was synthesized by adapting the incipient wetness impregnation procedure from De Schouwer et al. ${ }^{26}$ First, $1 \mathrm{~g}$ of $\mathrm{ZrO}_{2}$ was impregnated with an aqueous solution of $\left(\mathrm{NH}_{3}\right)_{4} \mathrm{PdCl}_{2}$. After drying and calcining

Table 6. Fate of Pyrrolidine under the Optimized Reaction Conditions

\begin{tabular}{|c|c|c|c|c|c|c|c|}
\hline & \multirow[b]{2}{*}{ catalyst } & \multirow[b]{2}{*}{$\mathrm{Pb}$} & \multirow[b]{2}{*}{$\mathrm{H}_{2}$} & \multirow[b]{2}{*}{ conversion $[\%]$} & \multicolumn{3}{|c|}{ selectivity [\%] } \\
\hline & & & & & pathway $A^{b}$ & pathway $B^{c}$ & pathway $C^{d}$ \\
\hline 1 & $\mathrm{Pd} / \mathrm{BaSO}_{4}$ & - & - & 63 & 36 & 13 & 51 \\
\hline 2 & $\mathrm{Pd} / \mathrm{BaSO}_{4}$ & - & $\mathrm{x}$ & 35 & 6 & 34 & 60 \\
\hline 3 & $\mathrm{Pd} / \mathrm{ZrO}_{2}$ & - & - & 53 & 36 & 24 & 40 \\
\hline 4 & $\mathrm{Pd} / \mathrm{ZrO}_{2}$ & - & $\mathrm{x}$ & 56 & 38 & 21 & 41 \\
\hline 5 & $\mathrm{PdPb} / \mathrm{ZrO}_{2}(\mathrm{~B})$ & $\mathrm{x}$ & - & 50 & 8 & 64 & 28 \\
\hline 6 & $\mathrm{PdPb} / \mathrm{ZrO}_{2}(\mathrm{~B})$ & $\mathrm{x}$ & $\mathrm{x}$ & 58 & 5 & 53 & 42 \\
\hline
\end{tabular}

${ }^{a}$ Reaction conditions: pyrrolidine $(0.2 \mathrm{mmol}), 4 \mathrm{~mol} \% \mathrm{Pd}$, water $(2 \mathrm{~mL}), 6$ bar $\mathrm{N}_{2}$ or 2 bar $\mathrm{N}_{2}$ and $4 \mathrm{bar} \mathrm{H}_{2}, 235{ }^{\circ} \mathrm{C}, 1 \mathrm{~h}$ or $20 \mathrm{~min}\left(\right.$ for $\mathrm{Pd} / \mathrm{ZrO}_{2}$ ). ${ }^{b}$ Side product from Pathway A is pyrrole. "Pathway B" represents 1-pyrroline, 2-pyrrolidone, propionic acid and butyric acid. "Pathway C" represents $n$-butylamine and mass loss from solution, resulting in the formation of propane and other volatiles. 
(35 min, $400{ }^{\circ} \mathrm{C}, 2{ }^{\circ} \mathrm{C} / \mathrm{min}$, air) the obtained material, it was impregnated with an aqueous solution of $\mathrm{Pb}\left(\mathrm{NO}_{3}\right)_{2}(\mathrm{Pd}: \mathrm{Pb}=$ 3:1 molar ratio). The doubly impregnated support was then dried overnight at $60{ }^{\circ} \mathrm{C}$, granulated to $250-500 \mu \mathrm{m}$ particles, followed by calcination $\left(35 \mathrm{~min}, 400{ }^{\circ} \mathrm{C}, 2{ }^{\circ} \mathrm{C} / \mathrm{min}, 50 \mathrm{~mL} /\right.$ min $\left.\mathrm{O}_{2}\right)$ and reduction $\left(1 \mathrm{~h}, 600{ }^{\circ} \mathrm{C}, 2{ }^{\circ} \mathrm{C} / \mathrm{min}, 150 \mathrm{~mL} / \mathrm{min}\right.$ $\mathrm{H}_{2}$ ). The catalyst was stored under $\mathrm{N}_{2}$ until use.

Catalyst Characterization. XRD patterns were recorded with a Huber Guinier Camera G670 equipped with an image plate and utilizing Mo $\mathrm{K} \alpha_{1}$ radiation. TEM specimens were prepared by crushing the samples in powder form in an agate mortar and by suspending the resulting powder in ethanol. A drop of this suspension was deposited on a carbon-coated TEM grid. HAADF-STEM images and EDX elemental maps were collected using an aberration-corrected cubed FEI Titan operated at $200 \mathrm{kV}$, equipped with a Super-X detector for EDX analysis. SEM micrographs were recorded using a JEOL6010LV SEM after depositing a Pd/Au layer on the samples using a JEOL JFC-1300 autofine coater under Ar plasma for 20 s. For CO chemisorption experiments, $50 \mathrm{mg}$ of the catalyst sample was loaded into a tubular reactor, pretreated in a stream of $20 \mathrm{~mL} / \mathrm{min} \mathrm{He}$ at $130{ }^{\circ} \mathrm{C}$ (heating rate: $10^{\circ} \mathrm{C} / \mathrm{min}$ ) for $1 \mathrm{~h}$ and subsequently cooled to room temperature. For the titration of the Pd surface, the He flow was reduced to $10 \mathrm{~mL} / \mathrm{min}$, and pulses of $5 \mu \mathrm{L}$ of $100 \% \mathrm{CO}$ were given with an interval of 2 min. The $\mathrm{CO}$ concentration in the outlet stream was followed with a Pfeiffer Omnistar quadrupole mass spectrometer. From the amount of $\mathrm{CO}$ adsorbed on the sample, a dispersion was calculated on the assumption that one $\mathrm{CO}$ molecule adsorbs per accessible $\mathrm{Pd}$ atom. $\mathrm{N}_{2}$ physisorption measurements were performed using a Micromeritics 3Flex surface analyzer at -196 ${ }^{\circ} \mathrm{C}$. Before the measurements, the $100 \mathrm{mg}$ samples were outgassed at $150{ }^{\circ} \mathrm{C}$ for $6 \mathrm{~h}$ under vacuum. The XPS analyses were performed on a SSX 100/206 photoelectron spectrometer from Surface Science Instruments (U.S.A.) equipped with a monochromatized micro focused $\mathrm{Al} \mathrm{X}$-ray source (powered at $20 \mathrm{~mA}$ and $10 \mathrm{kV}$ ).

Catalytic Reaction. In a typical reaction, a solution of $\mathrm{L}$ proline in deionized water $(2 \mathrm{~mL}, 0.1 \mathrm{M})$ and a catalyst $(4 \mathrm{~mol}$ $\% \mathrm{Pd})$ were loaded into a stainless steel reactor $(11 \mathrm{~mL})$. Next, the reactor was sealed, and the atmosphere was flushed six times with $\mathrm{N}_{2}$. Then, after pressurizing the reactor with 2 bar $\mathrm{N}_{2}$ followed by 4 bar $\mathrm{H}_{2}$, the mixture was magnetically stirred at $500 \mathrm{rpm}$ and heated to $235^{\circ} \mathrm{C}$. After $6 \mathrm{~h}$, the reaction was quenched by cooling with water and ice. Afterward, the catalyst was separated from the solution by centrifugation. For recycling experiments, the separated catalyst was washed three times with deionized water and dried overnight at $60{ }^{\circ} \mathrm{C}$. The catalyst was reused in a reaction of $2 \mathrm{~h}$ using the optimized conditions that are described in this paragraph. In each run, $5-10 \%$ of fresh catalyst was added to make up for the catalyst that was lost during the recycling.

Product Analysis and Identification. To determine the conversion of L-proline and the selectivities to the different products, the reaction mixtures were analyzed by ${ }^{1} \mathrm{H}$ NMR. Samples were prepared by adding $300 \mu \mathrm{L}$ of the reaction mixture to $300 \mu \mathrm{L}$ of $\mathrm{D}_{2} \mathrm{O}$ containing an external standard (benzyl alcohol, $0.1 \mathrm{M}$ ). ${ }^{1} \mathrm{H}$ NMR spectra were recorded on a Bruker Ascend $400 \mathrm{MHz}$ spectrometer equipped with a BBO 5 $\mathrm{mm}$ atma probe and a sample case. The broad signal of water was suppressed by applying an adapted zgpr pulse program: p1 $9.75 \mu \mathrm{s}$; plw1 15W; plw9 5.7-05W; o1P on the resonance signal of water, determined and selected automatically. In addition to ${ }^{1} \mathrm{H}$ NMR, the products were also identified by gas chromatography coupled to mass spectrometry (GC-MS) with an Agilent 6890 GC, equipped with a HP-5 ms column, coupled to a 5973 MSD mass spectrometer. The identification of gaseous products was done using a Gasmet DX4000 FTIR gas analyzer. The IR data were processed with Calcmet Standard software version 12.161 .

\section{ASSOCIATED CONTENT}

\section{Supporting Information}

The Supporting Information is available free of charge on the ACS Publications website at DOI: 10.1021/acscatal.6b02561.

Particle size distribution of $\mathrm{PdPb} / \mathrm{ZrO}_{2}$, XPS data, theoretical diffraction pattern of $\mathrm{Pd}, \mathrm{N}_{2}$ physisorption, mass transfer considerations, recycling experiments, and product identification (PDF)

\section{AUTHOR INFORMATION}

\section{Corresponding Author}

*E-mail: dirk.devos@kuleuven.be.

\section{Notes}

The authors declare no competing financial interest.

\section{ACKNOWLEDGMENTS}

J.V. and F.D.S. thank Fonds Wetenschappelijk Onderzoek (FWO) and Agency for Innovation by Science and Technology (IWT) for doctoral fellowships. D.D.V. acknowledges IWT and FWO for research project funding. D.D.V. and C.E.A.K. acknowledge the Flemish government for long-term structural funding through Methusalem. D.D.V. and S.B. acknowledge Belspo (IAP-PAI 7/05) for financial support. S.B. is grateful for funding by the European Research Council (ERC starting grant no. 335078-COLOURATOMS). The authors also thank the Department of Chemistry, University of Cologne, Germany for use of their XRD equipment. Finally, the assistance of Karel Duerinckx, Werner Wouters, Walter Vermandel, Ivo Stassen, Dries Jonckheere, Sabina Accardo and Bart Bueken with ${ }^{1} \mathrm{H}$ $\mathrm{NMR}$, pressure reactors, $\mathrm{CO}$ chemisorption, $\mathrm{N}_{2}$ physisorption, SEM, gas phase FTIR and high-throughput XRD, respectively, is very much appreciated.

\section{ABBREVIATIONS}

DKP, diketopiperazine

\section{REFERENCES}

(1) Eller, K.; Henkes, E.; Rossbacher, R; Höke, H. Amines, Aliphatic. Ullmann's Encyclopedia of Industrial Chemistry, 6th ed.; Wiley-VCH Verlag: Weinheim, 2002; Vol. 2, pp 647-698.

(2) Malczewska-Jaskóła, K.; Jasiewicz, B.; Mrówczyńska, L. Chem.Biol. Interact. 2016, 243, 62-71.

(3) Bujnowski, K.; Synoradzki, L.; Zevaco, T.; Dinjus, E. Preparation of new rifamycin derivatives as antibacterial agents. Patent PL 220114 B1, August 31, 2015.

(4) Johnson Matthey. Butanediol \& Co-Products. http:// davyprotech.com/what-we-do/licensed-processes-and-coretechnologies/licensed-processes/butanediol-thf-gbl/specification (accessed March 19, 2016).

(5) Breuer, M.; Ditrich, K.; Habicher, T.; Hauer, B.; Ke $\beta$ eler, M.; Stürmer, R.; Zelinski, T. Angew. Chem., Int. Ed. 2004, 43, 788-824.

(6) Demain, A. L. Ind. Biotechnol. 2007, 3, 269-283.

(7) Tuck, C. O.; Perez, E.; Horvath, I. T.; Sheldon, R. A.; Poliakoff, M. Science 2012, 337, 695-699. 
(8) Lammens, T. M.; Franssen, M. C. R.; Scott, E. L.; Sanders, J. P. M. Biomass Bioenergy 2012, 44, 168-181.

(9) Sanders, J.; Scott, E.; Weusthuis, R.; Mooibroek, H. Macromol. Biosci. 2007, 7, 105-117.

(10) Teng, Y.; Scott, E. L.; van Zeeland, A. N. T.; Sanders, J. P. M. Green Chem. 2011, 13, 624-630.

(11) Teng, Y.; Scott, E. L.; Witte-van Dijk, S. C. M.; Sanders, J. P. M. New Biotechnol. 2016, 33, 171-178.

(12) Wang, B.; Li, O.; Zhang, Z.; Fan, Q.; Li, Z.; Wu, C.; Zhang, P.; Chen, $\mathrm{X}$. One kind of device system for joint production of amino acids and analogs thereof. Patent CN 204724028 U, October 28, 2015.

(13) Yuan, F.; Wang, Q.; Yang, P.; Tian, Y.; Cong, W. Sep. Purif. Technol. 2015, 153, 51-59.

(14) Lin, D.; Zhao, Q.; Yan, M. J. Appl. Polym. Sci. 2016, 133, 43580.

(15) But, A.; Le Nôtre, J.; Scott, E. L.; Wever, R.; Sanders, J. P. M. ChemSusChem 2012, 5, 1199-1202.

(16) Matthessen, R.; Claes, L.; Fransaer, J.; Binnemans, K.; De Vos,

D. E. Eur. J. Org. Chem. 2014, 2014, 6649-6652.

(17) Claes, L.; Matthessen, R.; Rombouts, I.; Stassen, I.; De Baerdemaeker, T.; Depla, D.; Delcour, J. A.; Lagrain, B.; De Vos, D. E. ChemSusChem 2015, 8, 345-352.

(18) Claes, L.; Verduyckt, J.; Stassen, I.; Lagrain, B.; De Vos, D. E. Chem. Commun. 2015, 51, 6528-6531.

(19) Tamura, M.; Tamura, R.; Takeda, Y.; Nakagawa, Y.; Tomishige,

K. Chem. Commun. 2014, 50, 6656-6659.

(20) Tamura, M.; Tamura, R.; Takeda, Y.; Nakagawa, Y.; Tomishige,

K. Chem. - Eur. J. 2015, 21, 3097-3107.

(21) Lawson, A. Process for the production of amines. U.K. Patent 1008594-A, July 3, 1963.

(22) Dawes, G. J. S.; Scott, E. L.; Le Nôtre, J.; Sanders, J. P. M.; Bitter, J. H. Green Chem. 2015, 17, 3231-3250.

(23) Fu, J.; Lu, X.; Savage, P. E. Energy Environ. Sci. 2010, 3, 311317.

(24) Snare, M.; Kubickova, I.; Maki-Arvela, P.; Eranen, K.; Murzin, D. Y. Ind. Eng. Chem. Res. 2006, 45, 5708-5715.

(25) Le Nôtre, J.; Witte-van Dijk, S. C. M.; van Haveren, J.; Scott, E. L.; Sanders, J. P. M. ChemSusChem 2014, 7, 2712-2720.

(26) De Schouwer, F.; Claes, L.; Claes, N.; Bals, S.; Degrève, J.; De Vos, D. E. Green Chem. 2015, 17, 2263-2270.

(27) Schäfer, M.; Böttcher, A.; Kramer, A.; Höhn, A.; Kaczmarek, R.; Henkes, E. Preparation of pyrrole and pyridine. U.S. Patent US 6,538,139 B1, March 25, 2003.

(28) Kliewer, C. J.; Bieri, M.; Somorjai, G. A. J. Phys. Chem. C 2008, 112, 11373-11378.

(29) Furukawa, S.; Suga, A.; Komatsu, T. ACS Catal. 2015, 5, 12141222.

(30) Ding, L.; Yi, H.; Zhang, W.; You, R.; Cao, T.; Yang, J.; Lu, J.; Huang, W. ACS Catal. 2016, 6, 3700-3707.

(31) Jbir, I.; Couble, J.; Khaddar-Zine, S.; Ksibi, Z.; Meunier, F.; Bianchi, D. ACS Catal. 2016, 6, 2545-2558.

(32) Shi, C.; Zhang, P. Appl. Catal., B 2012, 115-116, 190-200.

(33) Faticanti, M.; Cioffi, N.; De Rossi, S.; Ditaranto, N.; Porta, P.; Sabbatini, L.; Bleve-Zacheo, T. Appl. Catal., B 2005, 60, 73-82.

(34) Hirano, T.; Kazahaya, Y.; Nakamura, A.; Miyao, T.; Naito, S. Catal. Lett. 2007, 117, 73-78.

(35) Lu, J.; Behtash, S.; Heyden, A. J. Phys. Chem. C 2012, 116, 14328-14341.

(36) Ahmadi, M.; Nambo, A.; Jasinski, J. B.; Ratnasamy, P.; Carreon, M. A. Catal. Sci. Technol. 2015, 5, 380-388. 